\title{
Nitrogen-sulphur use economics in rapeseed productivity at Rampur, Chitwan, Nepal
}

\begin{abstract}
Nitrogen and sulfur are yield limiting factors for rapeseed production in the sandy loam soil (Inceptisols) of the Chitwan, Nepal. A field experiment was conducted to study the effect of different rate of nitrogen and sulphur application on plant nutrient uptake, yield, oil content and economic nutrient use rate of the rapeseed production. The experiment consisted of twelve treatments with different combinations of nitrogen and sulfur was laid out in the factorial treatments arranged in Randomized Complete Block Design (RCBD) with three replications. Factors included three levels of nitrogen $\left(0,60\right.$, and $\left.100 \mathrm{~kg} \mathrm{~N} \mathrm{ha}^{-1}\right)$ and four levels of sulfur $\left(0,10,25\right.$, and $\left.50 \mathrm{~kg} \mathrm{~S}^{-1}\right)$ respectively. The highest yield was obtained from $100 \mathrm{~kg} \mathrm{~N} \mathrm{ha}^{-1}$ as compared to the control $\left(\mathrm{N}_{0}\right)$. Seed yield and seed oil content of the rapeseed significantly increased with the sulfur level. Application of $25 \mathrm{~kg} \mathrm{~S}$ ha produced the highest yield. Similarly, $10 \mathrm{~kg} \mathrm{~S} \mathrm{ha}{ }^{-1}$ produced the highest oil content $(38.37 \%)$ compared to the control $(36.41 \%)$. The interaction effect of nitrogen and sulfur at the rate of $100 \mathrm{~kg} \mathrm{~N} \mathrm{ha}^{-1}$ and $10 \mathrm{~kg} \mathrm{~S} \mathrm{ha}^{-1}$ produced significantly highest yield than control. The seed oil content of the rapeseed was also significantly influenced by the combined application of nitrogen and sulfur. The highest oil content (39.53\%) was observed from the plot with $60 \mathrm{~kg} \mathrm{~N} \mathrm{ha}^{-1}$ and $50 \mathrm{~kg} \mathrm{~S}$ ha-1 which was at par with $100 \mathrm{~kg} \mathrm{~N} \mathrm{ha}^{-1}$ and $10 \mathrm{~kg} \mathrm{~S} \mathrm{ha}^{-1}$ compared to the control plot which has the minimum oil content in the seed (35.57\%). Sulfur level affected significantly the soil total nitrogen and the highest of which was observed from the

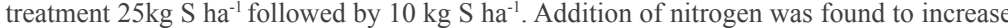
the plant nitrogen content but did not make significant effect on increasing plant sulphur content and oil content. There was increase in incremental yield and marginal profit with the increasing dose of $\mathrm{N}$ as the highest $\mathrm{B}: \mathrm{C}$ ratio was obtained from $100 \mathrm{~kg} \mathrm{~N} \mathrm{ha}^{-1}$ which was significantly greater than $60 \mathrm{~kg} \mathrm{~N} \mathrm{ha}^{-1}$ and control. There was no response in yield by the

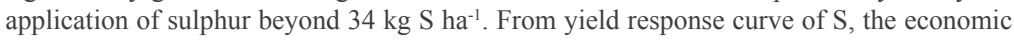
optimum sulphur rate (EOSR) was obtained as $30 \mathrm{~kg} \mathrm{~S} \mathrm{ha}^{-1}$. In our finding, Sulphur is less limiting factor for rapeseed production compared to Nitrogen. Balanced replenishment of Sulphur $\left(30 \mathrm{~kg} \mathrm{~S} \mathrm{ha}^{-1}\right)$ by crop uptake is sufficient to obtain optimum rapeseed productivity. Nitrogen dose can be increased (100 $\left.\mathrm{kg} \mathrm{N} \mathrm{ha}^{-1}\right)$ to that of recommended dose $\left(60 \mathrm{~kg} \mathrm{~N} \mathrm{ha}^{-1}\right)$ for maximizing rapeseed economic production. Various sources of $\mathrm{S}$ and varying level of $\mathrm{N}$ with improved varieties of rapeseed is a further subject of study in Chitwan district.
\end{abstract}

Volume 8 Issue 4 - 2018

\author{
Roshan Babu Ojha,' Bikram Basyal, ${ }^{2}$ Baburam \\ Khanal, ${ }^{3}$ Kesab Raj Pande ${ }^{4}$ \\ 'Soil Science Division, Nepal Agricultural Research Council, \\ Nepal \\ 2,3,4 Department of soil science and Agri-engineering, Agriculture \\ and Forestry University, Nepal
}

Correspondence: Roshan Babu Ojha, Soil Science Division, Nepal Agricultural Research Council, Nepal Email roshanbachhan@gmail.com

Received: August 13, 2017| Published: July 23, 2018

Keywords: nitrogen, sulphur use economics, oil content, rapeseed, sulfur

\section{Introduction}

$\mathrm{N}$ and $\mathrm{S}$ are the most limiting factor for rapeseed production. Apart from various factor, declining level of $\mathrm{N}$ and $\mathrm{S}$ is evident in decreasing level of the rapeseed productivity. Available soil $\mathrm{N}$ supplies are generally inadequate for optimum crop production. It was reported that the crop production appears to be limited by N, K, and Sin Chitwan condition. ${ }^{1}$ The productivity of rapeseed has been declining for last many years as reported from various parts of the country. ${ }^{1}$ Depletion of the organic matter in soil, use of single graded fertilizer in low amount, deficiency of nutrients (especially $\mathrm{N}, \mathrm{S}$, and B) have been recognized as the major cause for the declining rapeseed in the Chitwan valley. ${ }^{3}$ Interaction effect of the sulphur and nitrogen are directly related to the alteration of physiological and biochemical responses of crops, and so it should be studied in depth. ${ }^{4} \mathrm{~N}$ could be a significant strategy for improvement of growth and productivity of rapeseed and mustard. ${ }^{5}$ The study of the nitrogen and sulphur interaction is so required to help understand nutritional behavior of sulphur in relation to nitrogen nutrients and provide guidelines for evaluating the balanced fertilizer combination in order to optimize yield and quality of crops. ${ }^{6,7}$ Oilseed crops are the third most important crops of Nepal after cereals and legumes in both area and production. Rapeseed occupies $80 \%$ of the total area among the oilseed crops. ${ }^{8}$ which indicates the wide acceptance of the rapeseed oil by Nepalese people for cooking purpose. The productivity of rapeseed has been declining for last many years as reported from various parts of the country. ${ }^{2}$ Nepal, which was oilseed exporting country till early seventies, has turned into edible oil importing country (NORP, 1998/1999). So, this study aimed to evaluate rapeseed yield as influenced by N-S interaction and to find economic nutrient dose for farmers of inner-Terai regions for better profitability.

\section{Materials and methodology}

A field research was conducted at agronomy farm of Agriculture and Forestry University, Chitwan, Nepal with two factors, Nitrogen with three levels $\left(0,60,100 \mathrm{~kg} \mathrm{~N} \mathrm{ha}^{-1}\right)$ and Sulphur with four levels $\left(0,10,25,50 \mathrm{~kg} \mathrm{~S}^{-1}\right)$ were arranged in factorial randomized complete block design. Twelve treatments combination (N0S0, N0S10, N0S25, N0S50, N60S0, N60S10, N60S25, N60S50, N100S0, N100S10, $\mathrm{N} 100 \mathrm{~S} 25$, and N100S50) were replicated thrice with individual plot size $4 \times 2.1 \mathrm{~m}$. Elemental Sulphur (90\%) was used as a source of sulphur 
and Urea (46\%) was used as a source of Nitrogen. Preeti variety of rapeseed was selected as it is the recommended variety for the innerTerai region. Various soil parameters and plant parameters like oil content and yield were observed. Sampling of soil and plant was done after rapeseed harvesting and analyzed with standard lab procedure in Aastha Scientific Technology Lab, Kathmandu. Statistical analysis was done with the help of Gen Stat version 4. Data were subjected to normality test and linearity test. Normal data are used for two-way analysis of ANOVA. Means were separated at 5\% level of significance with Duncan's multiple range tests. Benefit-Cost ratio was calculated on the basis of standard procedure and all the cost related with labor, inputs, and farm cost are included. Total benefit was calculated on the basis of grain yield value. Nutrient use economics of sulphur was calculated on the basis of the method described by Havlin et.al.,

\section{Results and Discussion}

\section{Plant nitrogen and sulphur content and their uptake}

The main effect of sulphur and nitrogen was not found significant on the both plant nitrogen content and plant sulphur content of rapeseed but there found significant effect of sulphur application on plant sulphur content of rapeseed. Application of $10 \mathrm{t} \mathrm{S} \mathrm{ha}^{-1}$ provided the highest plant sulphur content of rapeseed which is significantly different with other doses of sulphur (Table 1). However, the interaction of sulphur and nitrogen application gave the significant result on plant nitrogen content. The interaction of $60 \mathrm{~kg} \mathrm{~N}^{-1}$ and $50 \mathrm{~kg} \mathrm{~S} \mathrm{ha-1}$ increased the highest plant nitrogen content which is at par with $100 \mathrm{~kg} \mathrm{~N} \mathrm{ha}^{-1}$ and $50 \mathrm{~kg} \mathrm{~S} \mathrm{ha}^{-1}$ application (Figure 1) but N-S interaction didn't significantly increase the plant sulphur content. The main effect of nitrogen application has significant effect on plant uptake of nitrogen by rapeseed plant. The highest nitrogen uptake $\left(12.46 \mathrm{~kg} \mathrm{ha}^{-1}\right)$ was obtained from $100 \mathrm{~kg} \mathrm{~N} \mathrm{ha}^{-1}$ which is significantly different with application of $60 \mathrm{~kg} \mathrm{~N} \mathrm{ha}^{-1}$ and control. Similarly, sulphur application has also significant effect on nitrogen uptake by the plant. The highest nitrogen uptake $\left(10.87 \mathrm{~kg} \mathrm{ha}^{-1}\right)$ was obtained from $25 \mathrm{~kg} \mathrm{~S} \mathrm{ha}{ }^{-1}$ however; it was not significantly differed with nitrogen uptake obtained from application of $50 \mathrm{~kg}$ and $10 \mathrm{~kg} \mathrm{~S}^{-1}$ (Table 2). Similarly, the main effect of nitrogen has significant effect on sulphur uptake by rapeseed. The highest sulphur uptake $(1.99 \mathrm{~kg}$ $\mathrm{ha}^{-1}$ ) was obtained from $100 \mathrm{~kg} \mathrm{~N} \mathrm{ha}^{-1}$ which is significantly different with $60 \mathrm{~kg}$ and $0 \mathrm{~kg} \mathrm{~N} \mathrm{ha}^{-1}$. Similarly, sulphur application has also the significant effect on plant uptake of sulphur by rapeseed. The highest sulphur uptake $\left(1.7 \mathrm{~kg} \mathrm{ha}^{-1}\right)$ was obtained from $10 \mathrm{~kg} \mathrm{~S} \mathrm{ha}^{-1}$ which was statistically similar with sulphur uptake obtained from $50 \mathrm{~kg} \mathrm{~S} \mathrm{ha}^{-1}$ and $25 \mathrm{~kg} \mathrm{~S} \mathrm{ha}^{-1}$ and significantly different than control (Table 2 ). Nitrogen and sulphur interaction has not significant effect on nitrogen and sulphur uptake by rapeseed (data not shown).

\section{Yield and oil content}

The main effect of nitrogen and sulphur application was found highly significant on the yield of rapeseed. The highest yield of rapeseed was found to be $0.59 \mathrm{t} \mathrm{ha}^{-1}$ from N100 which was significantly different than other nitrogen doses. Similarly, the highest yield was found to be 0.52 tha $^{-1}$ from application of $25 \mathrm{~kg} \mathrm{~S}^{-1} \mathrm{ha}^{-1}$ which was found statistically similar with $50 \mathrm{~kg}$ and $10 \mathrm{~kg} \mathrm{~S}^{-1}$ having yield as $0.50 \mathrm{tha}^{-1}$ and 0.45 tha $^{-1}$ respectively (Table 3 ). The interaction effect of nitrogen and sulphur was found highly significant on grain yield of rapeseed. The highest yield was obtained as 0.7 tha $^{-1}$ from N100S10 which was statistically similar with N100S50 and significantly different with rest treatments (Figure 2). The main effect of nitrogen was found highly significant in biological yield of rapeseed. The highest biological yield of rapeseed was found to be 2.83 tha $^{-1}$ obtained from N100 which was significantly different than other nitrogen doses. Similarly, the main effect of sulphur on biological yield of rapeseed was found highly significantly different. The highest biological yield of the rapeseed was found to be $2.59 \mathrm{t} \mathrm{ha}^{-1}$ obtained from S25 which is significantly higher than S10 and S50 (Table 3). The interaction effect of nitrogen and sulphur was not found significant in biological yield of rapeseed (data not shown). The oil content of rapeseed was not found significantly increases with increasing doses of nitrogen (Table 3) but oil content increased significantly with the application of sulphur. The highest oil content was $38.37 \%$ from $25 \mathrm{~kg} \mathrm{~S}^{-1}$ which was statistically similar with $36.41 \%$ and $37.28 \%$ obtained from $25 \mathrm{~kg} \mathrm{~S}^{-1}$ and $50 \mathrm{~kg} \mathrm{~S} \mathrm{ha}^{-1}$ respectively (Table 3 ). The interaction effect of nitrogen and sulphur was significantly affected by N60S50 gave maximum oil content similar with N100S10 (Figure 3). The N-S interaction in producing grain yield and oil content was found significant effect for rapeseed productivity.

Table I Effect of nitrogen and sulphur on $\mathrm{N}$ and $\mathrm{S}$ content of rapeseed at Rampur, Chitwan, 2015/2016

\begin{tabular}{lll}
\hline Treatments & Plant nitrogen (\%) & Plant sulphur (\%) \\
\hline N0 & 2.096 & 0.311 \\
N60 & 2.154 & 0.308 \\
NI00 & 2.167 & 0.349 \\
\hline LSD $(P=0.05)$ & NS & NS \\
SEm $( \pm)$ & 0.0832 & 0.0188 \\
\hline$S_{0}$ & 2.11 & $0.30 I^{\mathrm{b}}$ \\
$\mathrm{S}_{10}$ & 2.139 & $0.382^{\mathrm{a}}$ \\
\hline $\mathrm{S}_{25}$ & 2.108 & $0.298^{\mathrm{b}}$ \\
$\mathrm{S}_{50}$ & 2.199 & $0.31^{\mathrm{b}}$ \\
LSD $(\mathrm{P}=0.05)$ & $\mathrm{NS}$ & $0.0638^{*}$ \\
$\mathrm{SEm}( \pm)$ & $0.096 \mathrm{I}$ & $0.021^{\circ}$ \\
CV $(\%)$ & 13.5 & 20.2 \\
Grand mean & 2.139 & 0.323 \\
\hline
\end{tabular}

Means followed by the same letter in the column and row are not significantly different by DMRT $(\mathrm{P}<0.05)$, ${ }^{*}$ Significant at $5 \%$ level and ** significant at $1 \%$ level

Table 2 Effect of nitrogen and sulphur interaction on $\mathrm{N}$ and $\mathrm{S}$ uptake of rapeseed at Rampur, Chitwan 2015/2016

\begin{tabular}{lll}
\hline Treatments & $\begin{array}{l}\text { Nitrogen uptake } \\
(\text { kg ha-') }\end{array}$ & $\begin{array}{l}\text { Sulphur uptake } \\
\text { (kg ha-') }\end{array}$ \\
\hline $\mathrm{N} 0$ & $5.3 \mathrm{Ic}$ & $0.77^{\mathrm{c}}$ \\
$\mathrm{N} 60$ & $10.00^{\mathrm{b}}$ & $1.39^{\mathrm{b}}$ \\
$\mathrm{N} 100$ & $12.46^{\mathrm{a}}$ & $1.99^{\mathrm{a}}$ \\
\hline $\mathrm{LSD}(\mathrm{P}=0.05)$ & $2.33^{* *}$ & $0.33^{* *}$ \\
$\mathrm{SEm}( \pm)$ & 0.79 & 0.11 \\
\hline $\mathrm{S}_{0}$ & $5.62^{\mathrm{b}}$ & $0.79^{\mathrm{b}}$ \\
$\mathrm{S}_{10}$ & $9.72^{\mathrm{a}}$ & $1.70^{\mathrm{a}}$ \\
$\mathrm{S}_{25}$ & $10.87^{\mathrm{a}}$ & $1.52^{\mathrm{a}}$ \\
$\mathrm{S}_{50}$ & $10.82^{\mathrm{a}}$ & $1.54^{\mathrm{a}}$ \\
$\mathrm{LSD}^{\mathrm{a}}(\mathrm{P}=0.05)$ & $2.69^{* *}$ & $0.38^{* *}$ \\
\hline
\end{tabular}


Table continued...

\begin{tabular}{lll}
\hline Treatments & $\begin{array}{l}\text { Nitrogen uptake } \\
\text { (kg ha-') }\end{array}$ & $\begin{array}{l}\text { Sulphur uptake } \\
\text { (kg ha-') }\end{array}$ \\
\hline SEm $( \pm)$ & 0.92 & 0.13 \\
CV (\%) & 29.7 & 28.3 \\
Grand mean & 9.26 & 1.39
\end{tabular}

Means followed by the same letter in the column and row are not significantly different by DMRT $(\mathrm{P}<0.05)$, * Significant at $5 \%$ level and ** significant at $1 \%$ level

Table 3 Effect of nitrogen and sulphur on yield, biological yield and Oil Content of rapeseed at Rampur, Chitwan, 2015/2016

\begin{tabular}{|c|c|c|c|}
\hline Treatments & $\begin{array}{l}\text { Grain Yield } \\
\text { (t ha-') }\end{array}$ & Biological yield (t ha-') & $\begin{array}{l}\text { Oil } \\
\text { content } \\
(\%)\end{array}$ \\
\hline No & $0.25^{c}$ & $1.450^{c}$ & 36.61 \\
\hline N60 & $0.48^{b}$ & $2.308^{\mathrm{b}}$ & 36.89 \\
\hline NIO0 & $0.59^{a}$ & $2.833^{\mathrm{a}}$ & 37.85 \\
\hline $\operatorname{LSD}(P=0.05)$ & $0.078^{* *}$ & $0.32 I^{* *}$ & NS \\
\hline $\operatorname{SEm}( \pm)$ & 0.026 & 0.109 & 0.361 \\
\hline $\mathrm{S}_{0}$ & $0.27^{b}$ & $1.600^{c}$ & $36.4 I^{b}$ \\
\hline$S_{10}$ & $0.45^{a}$ & $2.133^{b}$ & $38.37^{a}$ \\
\hline $\mathrm{S}_{25}$ & $0.52^{\mathrm{a}}$ & $2.589^{a}$ & $37.28^{b}$ \\
\hline $\mathrm{S}_{50}$ & $0.50^{\mathrm{a}}$ & $2.467^{\mathrm{ab}}$ & $37.28^{b}$ \\
\hline $\operatorname{LSD}(P=0.05)$ & $0.09 * *$ & $0.37 I^{* *}$ & $1.224^{*}$ \\
\hline $\operatorname{SEm}( \pm)$ & 0.03 & 0.127 & 0.417 \\
\hline CV (\%) & 21.2 & 17.3 & 3.4 \\
\hline Grand Mean & 0.433 & 2.197 & 37.12 \\
\hline
\end{tabular}

Means followed by the same letter in the column and row are not significantly different by DMRT $(\mathrm{P}<0.05)$, * Significant at $5 \%$ level and ** significant at $1 \%$ level

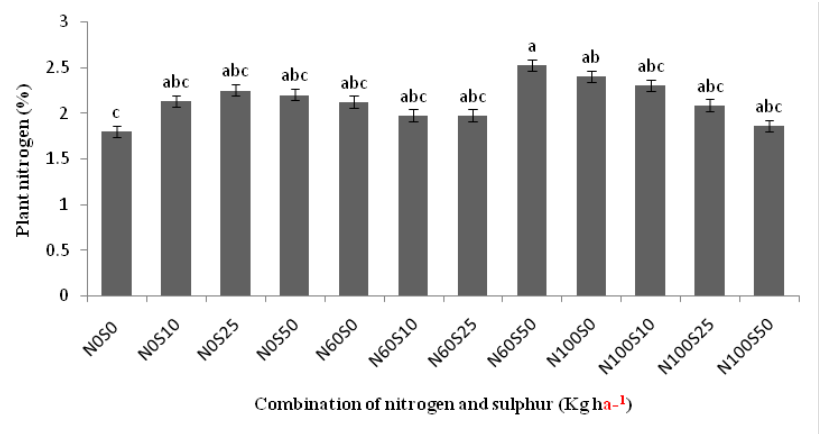

Figure I Effect of nitrogen and sulphur interaction in plant nitrogen content of the rapeseed at AFU, Rampur Chitwan.

\section{Economic optimum nutrient response}

The effect of nitrogen in the $\mathrm{BC}$ ratio was found highly significantly different. The highest $\mathrm{BC}$ ratio was found to be 1.14 from $100 \mathrm{~kg} \mathrm{~N} \mathrm{ha}^{-1}$ and the lowest $\mathrm{BC}$ ratio was 0.56 obtained from $0 \mathrm{~kg} \mathrm{~N} \mathrm{ha}^{-1}$. Similarly, the effect of sulphur was found highly significantly different on $\mathrm{BC}$ ratio of rapeseed. The highest $\mathrm{BC}$ ratio (1.05) was observed from $25 \mathrm{~kg}$ $\mathrm{S} \mathrm{ha}^{-1}$ and the lowest $\mathrm{BC}$ ratio was 0.62 obtained from $0 \mathrm{~kg} \mathrm{~S} \mathrm{ha}^{-1}$. The interaction effect of nitrogen and sulphur was not significantly different in $\mathrm{BC}$ ratio of rapeseed. However, combined application of N100S10 produced the highest $\mathrm{BC}$ ratio (1.39) and the lowest $\mathrm{BC}$ ratio was 0.48 obtained from N0S10 (Table 4).

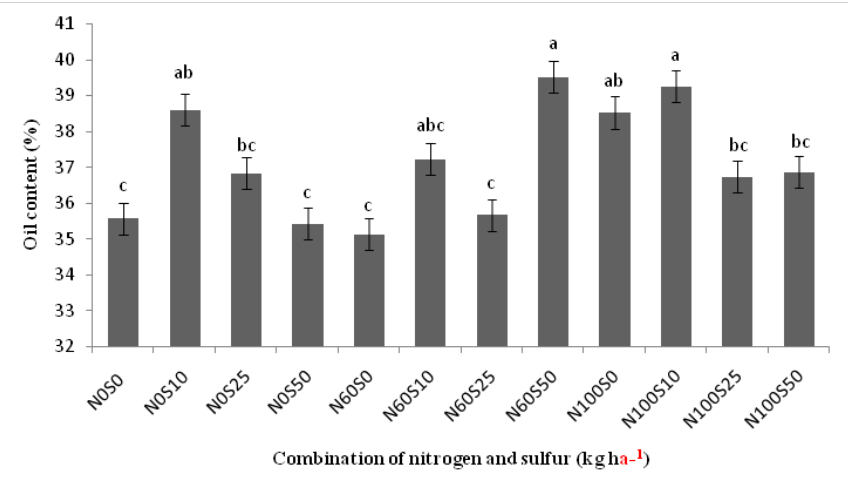

Figure 2 Effect of nitrogen and sulphur interaction in oil content of the rapeseed at AFU, Rampur, Chitwan, Nepal.

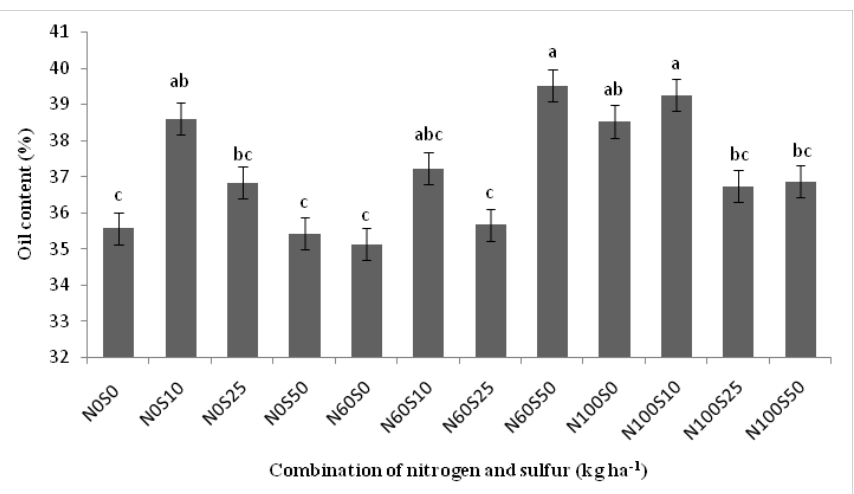

Figure 3 Effect of nitrogen and sulphur interaction in oil content of the rapeseed at AFU, Rampur, Chitwan, Nepal

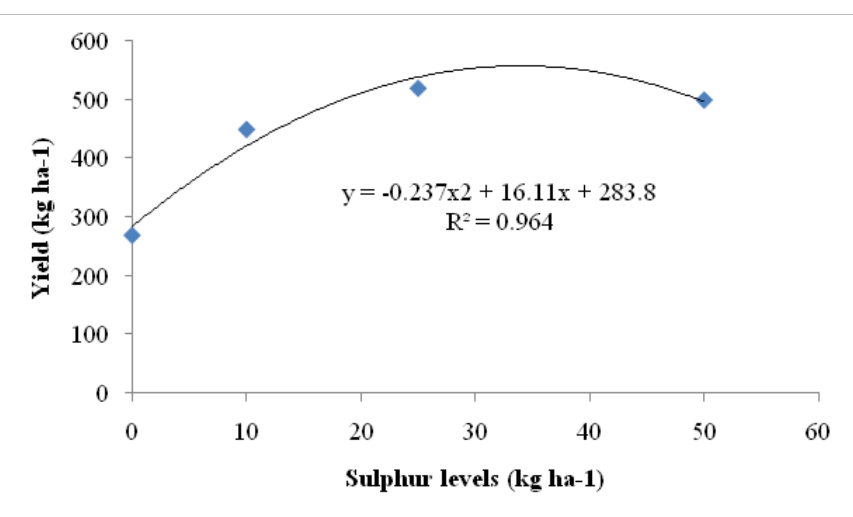

Figure 4 Response of rapeseed to different level of sulphur (kg ha- $\left.{ }^{-}\right)$grown at AFU, Rampur, Chitwan.

\section{Yield response curve by sulphur}

The quadratic function for yield $(\mathrm{Y})$ on the applied level of nutrients $(\mathrm{x})$ was obtained $\mathrm{Y}=-0.2372 \mathrm{x}^{2}+16.114 \mathrm{x}+283.81$ for sulphur with 0.96 coefficient of determination. Per unit output of sulphur was relatively higher than per unit output of nitrogen. Addition of sulphur (intercept value 16.11) showed better response in rapeseed productivity. But, the response of sulphur cannot be obtained beyond $34 \mathrm{~kg}$ of applied sulphur which is physical optima S dose. In case of Nitrogen quadratic function cannot be run to illustrate nutrient 
response curve. So, physical optima and economic optima cannot be calculated but there is increasing in incremental yield with the increasing doses of Nitrogen.

Table 4 Effect of nitrogen and sulphur interaction on $B C$ ratio of rapeseed at Rampur, Chitwan, 2015/2016

\begin{tabular}{|c|c|c|c|c|}
\hline Treatments & BC ra & & & \\
\hline & $\mathbf{N}_{0}$ & $\mathbf{N}_{60}$ & $\mathbf{N}_{100}$ & Row mean \\
\hline $\mathrm{S}_{0}$ & 0.5 & 0.67 & 0.67 & $0.62^{b}$ \\
\hline$S_{10}$ & 0.48 & 0.96 & 1.39 & $0.94^{a}$ \\
\hline $\mathrm{S}_{25}$ & 0.76 & I.0I & 1.27 & $1.05^{\mathrm{a}}$ \\
\hline$S_{50}$ & 0.5 & 1.03 & 1.24 & $0.92^{\mathrm{a}}$ \\
\hline Column Mean & $0.56 c$ & $0.94^{b}$ & $1.14^{a}$ & 0.88 \\
\hline $\operatorname{LSD}(P=0.05)$ & NS & & $\mathrm{N}: 0.15^{* *}$ & S: $0.17^{* *}$ \\
\hline SEm $( \pm)$ & 0.103 & & 0.052 & 0.059 \\
\hline CV (\%) & 20.3 & & & \\
\hline
\end{tabular}

\section{Physical maxima and economic optima of fertilizer use}

\section{Physical maximum dose}

Physical maximum dose of any nutrient occurs at any point where, $\frac{d y}{d x}=0$ (First derivative of response curve equals to zero)

\section{a. Sulphur}

$Y=-0.2372 S^{2}+16.114 S+283.81$

Differentiating the equation with respect to $\mathrm{S}$ on both sides,

$$
\frac{\mathrm{dy}}{\mathrm{ds}}=\frac{\mathrm{d}(-0.2372 \mathrm{~S} 2+16.114 \mathrm{~S}+283.81)}{\mathrm{ds}}
$$

$=2\left(-0.2372 \mathrm{~S}^{2-1}+16.114 \mathrm{~S}^{1-1}+0\right) / \mathrm{ds}$

$=16.114-0.4744 \mathrm{~S}$

Equating the differentiating product with 0 ,

$16.114-0.4744 \mathrm{~S}=0$

$$
\begin{aligned}
& S=16.114 / 0.4744 \\
& \mathbf{S}=\mathbf{3 3 . 9 7} \mathbf{k g h a}^{-\mathbf{1}}
\end{aligned}
$$

\section{Economic optimum dose}

Economic optimum dose occurs at point where, first derivative of response curve equals to unit price ratio of applied nutrients $(\mathrm{Pn})$ to produce $(\mathrm{Pp})$

$$
\text { i.e. } \frac{d y}{d x}=\frac{P n}{P p}
$$

\section{a. Sulphur}

$202.671 / 100=16.114-0.4744 \mathrm{~S}$

$2.0267=16.114-0.4744 \mathrm{~S}$

$\mathrm{S}=(16.114-2.0267) / 0.4744$

\section{$S=14.0873 / 0.4744$}

\section{$\mathrm{S}=29.69 \mathrm{~kg} \mathrm{ha}^{-1}$}

Thus, the economic optimum dose of sulphur was $29.69 \mathrm{~kg} \mathrm{~S} \mathrm{ha}^{-1}$.

Application of different level of nitrogen significantly influenced seed yield of rapeseed. Similar was reported by Karamzadeh et. al., ${ }^{10}$ Ozturk ${ }^{11}$;Cheemaet al., ${ }^{12}$ The application of nitrogen increased the yields of seed and oil, principally through increased production of seeds by a larger number of pods. ${ }^{13}$ Application of different level of sulphur significantly increased the seed yield of rapeseed. The grain yield varied between 0.27 tha $^{-1}$ from application of $0 \mathrm{~kg} \mathrm{~S} \mathrm{ha}^{-1}$ to 0.52 tha $^{-1}$ from application of $25 \mathrm{~kg} \mathrm{~S} \mathrm{ha}^{-1}$. This finding was also supported by Sharif. ${ }^{14}$ Similar result was also reported by Khalid et al.,(2009) who stated that application of $40 \mathrm{~kg} \mathrm{~S} \mathrm{ha}^{-1}$ produced the highest seed yield. Seed yield of rapeseed was significantly influenced by the interaction effect of nitrogen and sulphur. Similar findings were also reported by Cheema et al., ${ }^{15}$; Kumar et al. ${ }^{16}$ The highest seed yield was achieved from the combination of N100S10 which was also at par with N100S50. And the lowest yield was achieved from the treatment NOS0. Sulphur also helps in assimilation of nitrogen thereby producing more nitrogenous metabolites and photo synthates, which help to increase the total dry matter resulting the more yield. The increase in yield with the various combinations of nitrogen and sulphur may be due to the positive effect of those combinations on major yield attributing characters viz: number of siliqua per plant, seed per siliqua and 1000 seed weight of rapeseed. Effect of nitrogen in oil content of rapeseed was not found significant. It was also reported that application of different nitrogen level did not affect the oil content of rapeseed. ${ }^{17}$ However, maximum oil content was achieved from application of $100 \mathrm{~kg} \mathrm{ha}^{-1}$ nitrogen and the lowest oil content was achieved from $0 \mathrm{~kg} \mathrm{ha}^{-1}$ nitrogen. These positive findings are in line with Mansoori ${ }^{18}$ who stated that with increasing nitrogen levels from $0 \mathrm{~kg} \mathrm{ha}^{-1}$ to $80 \mathrm{~kg} \mathrm{ha}^{-1}$, the seed oil percentage increased from $34.91 \%$ to $39.83 \%$. Cheema et al. ${ }^{15}$ who stated that maximum oil content was obtained from $120 \mathrm{~kg} \mathrm{~N}$ and $125 \mathrm{~kg} \mathrm{~S}$ and the minimum was obtained from $60 \mathrm{~kg} \mathrm{~N}$ and $0 \mathrm{~kg} \mathrm{~S}$. These findings are also supported by Ahmad et al., ${ }^{19}$ Kumar et al., ${ }^{16}$ The effect of the soil-applied sulphur was found significant on the soil total nitrogen in rapeseed field. This finding was in line with Mirzashahi et al., ${ }^{20}$ who stated that soil nitrogen content increased with application of sulphur compared to control. Soil available sulphur increases with the increasing level of sulphur from $0 \mathrm{~kg} \mathrm{ha}^{-1}$ to $25 \mathrm{~kg} \mathrm{ha}^{-1}$. Similar positive findings were also supported by Chattopaddhyay \& Ghosh. ${ }^{21}$ The highest soil available sulphur was achieved from S25 (0.262\%) and the lowest was achieved from S0 $(0.240 \%)$. This might be due to use of elemental sulphur as the source of sulphur. Friesen ${ }^{22}$ reported the leaching loss of applied sulphur up to $20 \%$ from elemental sulphur compared to $50 \%$ from ammonium sulfate.

\section{Conclusion}

Application of $100 \mathrm{~kg} \mathrm{~N} \mathrm{ha}^{-1}$ produced the highest yield of rapeseed with positive influence in plant nitrogen content and nitrogen uptake from soil. The highest oil content was also obtained from $100 \mathrm{~kg} \mathrm{~N} \mathrm{ha}^{-1}$ though the effect was not significant. Similarly, application of $25 \mathrm{~kg} \mathrm{~S}$ $\mathrm{ha}^{-1}$ produced the highest yield which was not significantly differed with yield from $10 \mathrm{~kg}$ and $50 \mathrm{~kg} \mathrm{~S} \mathrm{ha}^{-1}$ which is helpful to increase plant sulphur content and sulphur uptake from soil. Combined application of $100 \mathrm{~kg} \mathrm{Nha}{ }^{-1}$ and $10 \mathrm{~kg} \mathrm{~S} \mathrm{ha}^{-1}$ produced the highest yield $(0.70 \mathrm{t}$ $\mathrm{ha}^{-1}$ ) which was also similar with the combination of $100 \mathrm{~kg} \mathrm{~N} \mathrm{ha}^{-1}$ 
and $50 \mathrm{~kg} \mathrm{~S} \mathrm{ha}^{-1}$. In case of oil content, the highest was produced by interaction of N60S50 level however; it was not significantly differed with combination of N100S10, which have the highest yield. The response level of sulphur seems more than nitrogen during interaction. Increasing doses of $\mathrm{N}$ produce the increase in marginal benefit, highest $\mathrm{B}: \mathrm{C}$ ratio was obtained from $100 \mathrm{~kg} \mathrm{~N} \mathrm{ha}^{-1}$. However, increasing level of sulphur did not produce increasing marginal profit as the highest $\mathrm{B}: \mathrm{C}$ ratio was obtained from $25 \mathrm{~kg} \mathrm{~S}$ ha-1 which is significantly higher than control but similar with the application of $10 \mathrm{~kg} \mathrm{~S}^{-1}$ and $50 \mathrm{~kg}$ $\mathrm{S} \mathrm{ha}{ }^{-1}$. Yield response of $\mathrm{S}$ cannot be obtained beyond $34 \mathrm{~kg} \mathrm{~S} \mathrm{ha}^{-1}$ and the application $30 \mathrm{~kg} \mathrm{~S}^{-1}$ is the economic optimum nutrient response rate which is slightly higher with recommended dose $(25 \mathrm{~kg}$ $\left.\mathrm{S} \mathrm{ha}^{-1}\right)$. Application of elemental sulphur as the source of sulphur requires microbial oxidation to become available to the plant in sulfate $\left(\mathrm{SO}_{4}^{2-}\right)$ form. Response of sulphur fertilizer to the plant was delayed. Moreover, elemental sulphur due to its acidifying properties affects the availability of the other nutrients reducing the soil $\mathrm{pH}$. Additionally, incremental yield and incremental marginal profit from $\mathrm{N}$ was obtained up to $100 \mathrm{~kg} \mathrm{~N} \mathrm{ha}^{-1}$. Hence, the further research using the various sources of the sulphur and various level of $\mathrm{N}$ along with improved varieties of rapeseed is recommended.

\section{Acknowledgements}

Authors would like to express their deep gratitude to Nepal Agriculture Research Development Fund (NARDF) for funding. We would also like to thank Oilseed research program for providing seed materials. We acknowledge the help of Mr. Raju Lamichhane and the entire soil science department of Agriculture and Forestry University without which this work is not possible.

\section{Conflict of interest}

The author declares there is no conflict of interest.

\section{References}

1. Khatri-Chhetri TB. Assessment of soil test procedures for available boron and zinc in soils of the Chitwan Valley, Nepal. University of Wisconsin-Madison. 1982.

2. Shrivastav SV, Neupane DP. Long term fertility trial of maize toria rotation at ARS, Rampur. 1998; 136-142.

3. Rijal SP. Soil Fertility Decline in Nepal: Problem and Strategy. Nepal Journal of Science and Technology. 2001;3(1).

4. Extension NA. Effects of Interaction Between Nitrogen, Sulphur and Variety on Maize Grain Nitrogen and Sulphur Content At Samaru, Zaria. International Journal of Science and Nature. 2015;6(2):219-223.

5. Anjum NA, Gill SS, Umar S, et al. Improving growth and productivity of oleiferous Brassicas under changing environment: significance of nitrogen and sulphur nutrition, and underlying mechanisms. The Scientific World Journal. 2012;657808.

6. Fazili IS, Jamal A, Ahmad S. et al. Interactive effect of sulphur and nitrogen on nitrogen accumulation and harvest in oilseed crops differing in nitrogen assimilation potential. Journal of plant nutrition. 2008;31(7):1203-1220.
7. Jamal A, Moon YS, Abdin MZ. Enzyme activity assessment of peanut (Arachis hypogea L.) under slow-release sulphur fertilization. Australian Journal of Crop Science. 2010;4(3):169-174.

8. Ghimire TB. Technical Publication Thesis Grants. National Agricultural Research and Development Fund, Nepal. 2001; 18 pp.

9. Havlin JL, Tisdale SL, Nelson WL. Soil Fertility and Fertilizers: An Introduction to Nutrient Management. 8th ed, PHI Learning Pvt. Ltd. Delhi, India, 2014.

10. Karamzadeh A, Mobasser HR, Ramee V, et al. Effects of nitrogen and seed rates on yield and oil content of canola (Brassica napus L.). American-Eurasian J Agric \& Environ Sci. 2010;8(6):715-721.

11. Ozturk O. Effects of source and rate of nitrogen fertilizer on yield, yield components and quality of winter rapeseed (Brassica napus L.). Chilean Journal of Agricultural Research. 2010;70(1):132-141.

12. Cheema MA, Saleem MF, Muhammad N, et al. Impact of rate and timing of nitrogen application on yield and quality of canola (Brassica napus L.). Pakistan Journal of Botany. 2010;42(3):1723-1731.

13. Allen EJ, Morgan DG. A quantitative analysis of the effects of nitrogen on the growth, development and yield of oilseed rape. The Journal of Agricultural Science. 1972;78(2):315-324.

14. Sharifi RS. Study of yield, yield attribute and dry matter accumulation of canola (Brassica napus L.) cultivars in relation to sulphur fertilizer. International Journal of Agriculture And Crop Scien Ces 2012;4(7):409-415.

15. Cheema MA, Ali A, Saleem MF, et al. Interactive Effects of Nitrogen and Sulphur on the Growth, Seed Yield and Oil Quality of Canola. Pakj life soc sci. 2003;1(1):09-12.

16. Kumar V, Nath P, Kumar R, et al. Interactive effect of sulphur and nitrogen on growth, yield and quality of indian mustard (brassica juncea L.) International Journal of Science and Nature. 2008;181(4):193-199.

17. Singh BP, Prakash OM, Singh B. et al. Comparative performance of Indian mustard (Brassica juncea) genotypes in relation to sulphur fertilization. Indian Journal of Agronomy. 2002;47(4):531-536.

18. Mansoori I. Response of canola to nitrogen and sulphur fertilizers. $J$ Agric Crop Sci. 2012;4(1):28-33.

19. Ahmad A, Abraham G, Abdin M Z. Physiological investigation of the impact of nitrogen and sulphur application on seed and oil yield of $\begin{array}{ll}\text { rapeseed (Brassica campestris } & \text { L.) and mustard (Brassica juncea }\end{array}$ L. Czern. and Coss.) genotypes. Journal of Agronomy and Crop Science. 1999;183(1):19-25.

20. Mirzashahi K, Pishdarfaradaneh M, Nourgholipour F. Effects different rates of nitrogen and sulphur application on canola yield in North of Khuzestan. Journal of Research in Agricultural Science. 2010;6(2):107112 .

21. Chattopaddhyay S, Ghosh GK. Response of rapeseed (Brassica juncea L.) to various sources and levels of sulphur in red and lateritic soils of West Bengal, India. International Journal of Plant Animal and Environmental Sciences. 2012;2(4):50-59.

22. Friesen DK. Fate and efficiency of sulphur fertilizer applied to food crops in West Africa. Alleviating Soil Fertility Constraints to Increased Crop Production in West Africa. 1991:59-68. 